\title{
Apatite Microstructure and Composition in Manganese Formation of Eastern Ghats, Orissa, India
}

\author{
Subhasmita Jena ${ }^{1}$, B.K. Mohapatra ${ }^{1}$ and P. P. Singh ${ }^{2}$ \\ ${ }^{1}$ Institute of Minerals and Materials Technology, Bhubaneswar \\ ${ }^{1}$ Geology Department, Utkal University, Bhubaneswar \\ *Corresponding Author: bkmohapatra@immt.res.in
}

\begin{abstract}
Apatite grains in a stratabound manganese ore body from Eastern Ghats in Leliguma, Koraput district south Orissa, India were studied under optical and electron microscope. Apatite shows bimodal occurrence: one associated with granitelpegmatitic phase and other with manganese phase, and exhibits different microstructure and composition. Apatite in pegmatitic association (occurring as inclusion in quartz and feldspar) is small in size and occurs as subhedral grains having irregular boundaries and poor in manganese content (MnO: 0.16\%). Apatite associated with manganese mineral phases (cryptomelane / romanechite) is mostly euhedral, relatively larger in size, contains higher manganese value, and exhibits some peculiar features like twinning, zoning, overgrowth, and occasionally contains inclusion of quartz and feldspar grains.
\end{abstract}

Apatite grains occurring as inclusions within quartz and feldspar are of hydrothermal origin and formed along with pegmatitic minerals. Such apatite is almost devoid of manganese but relatively enriched in $\mathrm{Sr}, \mathrm{F}$ and LREE content. The apatite in manganese mineral association formed during supergene process. The apatite of latter generation appears as idiomorphic crystals; contains up to $6.85 \%$ of $\mathrm{MnO}$ in solid solution and shows relatively higher HREE values. The higher HREE values may be due to its derivation from stratiform Mn-ore bodies and associated granitised rock during remobilization, solution and precipitation of Mn -rich fluid along structurally weak planes resulting in development of a stratabound ore body.

Key words: Apatite, Eastern Ghats rocks, Manganese ore

\section{INTRODUCTION}

Apatite is one of the common accessory minerals found in crustal rocks and its presence and distribution are often used to make a model on the geologic processes such as mantle melting, hydrothermal processes etc. [1,2]. Compositions of apatite at many places relate to the processes involved. Apatite structure also accommodates some RE elements. It is often found as minor minerals in manganese ore. 
Naturally occurring apatite is represented by $\mathrm{Ca}_{10}\left(\mathrm{PO}_{4}\right)_{6} \mathrm{~F}_{2}$, with many substitutions possible for $\mathrm{Ca}, \mathrm{P}$ and $\mathrm{F}$. Minor replacement of $\mathrm{Ca}$ in natural apatite is mainly by $\mathrm{Na}, \mathrm{Sr}, \mathrm{Mn}$ and the REE. Substitution of $\mathrm{REE}^{3+}$ for $\mathrm{Ca}^{2+}$ in apatite is reported by some authors [3, 4]. The most common substitution for $\mathrm{P}$ is by $\mathrm{Si}$. REE distribution in a particular apatite depends not only on the apatite structure, but also upon the chemical characteristics of the melt, rock or fluid reservoir from which the apatite crystallized / formed [5]. Further, apatite forming at different stages may have a different REE concentration and distribution [6].

The Eastern Ghats Belt in south Orissa and Andhra Pradesh, India comprises a group of regionally metamorphosed (granulite facies) rocks represented by quartzite, quartz-feldspargarnet-silimanite \pm graphite gneiss (khondalite), granite gneiss and calc silicate rocks with intercalation of manganese occurrence. The manganese ores of south Orissa are low-grade in nature and have high phosphorus contents. Apatite is known to be the major contributor of phosphorus [7, 8]. Occurrence of apatite is reported from several associations. Acharya et al [9] and Bhattacharya et al [8] reported apatite in Mn-ores from Nishikhal region, Orissa and Grabham-Garividi belt, AP of Eastern Ghats respectively.

Geological map on 1:50000 scale around Leliguma-Koka sector of Koraput district, south Orissa (Toposheet no. $65 \mathrm{M} / 3$ ) is shown in Fig. 1. The area forms an integral part of Eastern Ghats complex comprising of calc-silicate, charnockite, khondalite, granite gneiss and Mn-ore. Some of these country rocks, especially granite gneiss and khondalite are traversed by small scale quartz and pegmatite veins. These rocks are metamorphosed to granulite facies.

The manganese ore in this area (Fig.1) generally shows two modes of occurrence: 1) As layer body within granite gneiss extending in a NW-SE direction near Koka (grouped under stratiform category). These types of ore bodies occur in tabular form and extend > 500mts in length and $>30 \mathrm{mts}$ in width. 2) As linear ore body cutting the granite gneiss in E-W directions near Leliguma (grouped under stratabound category).

The apatites in this ore body are recorded in two associations: one with silicate minerals and other with manganese minerals. No apatite is found to be associated with manganese mineral of stratiform ore body. The present report highlights the microstructural and compositional variation of apatite in both these association with a view to establish the genesis of apatite in the stratabound category of manganese ore bodies. 


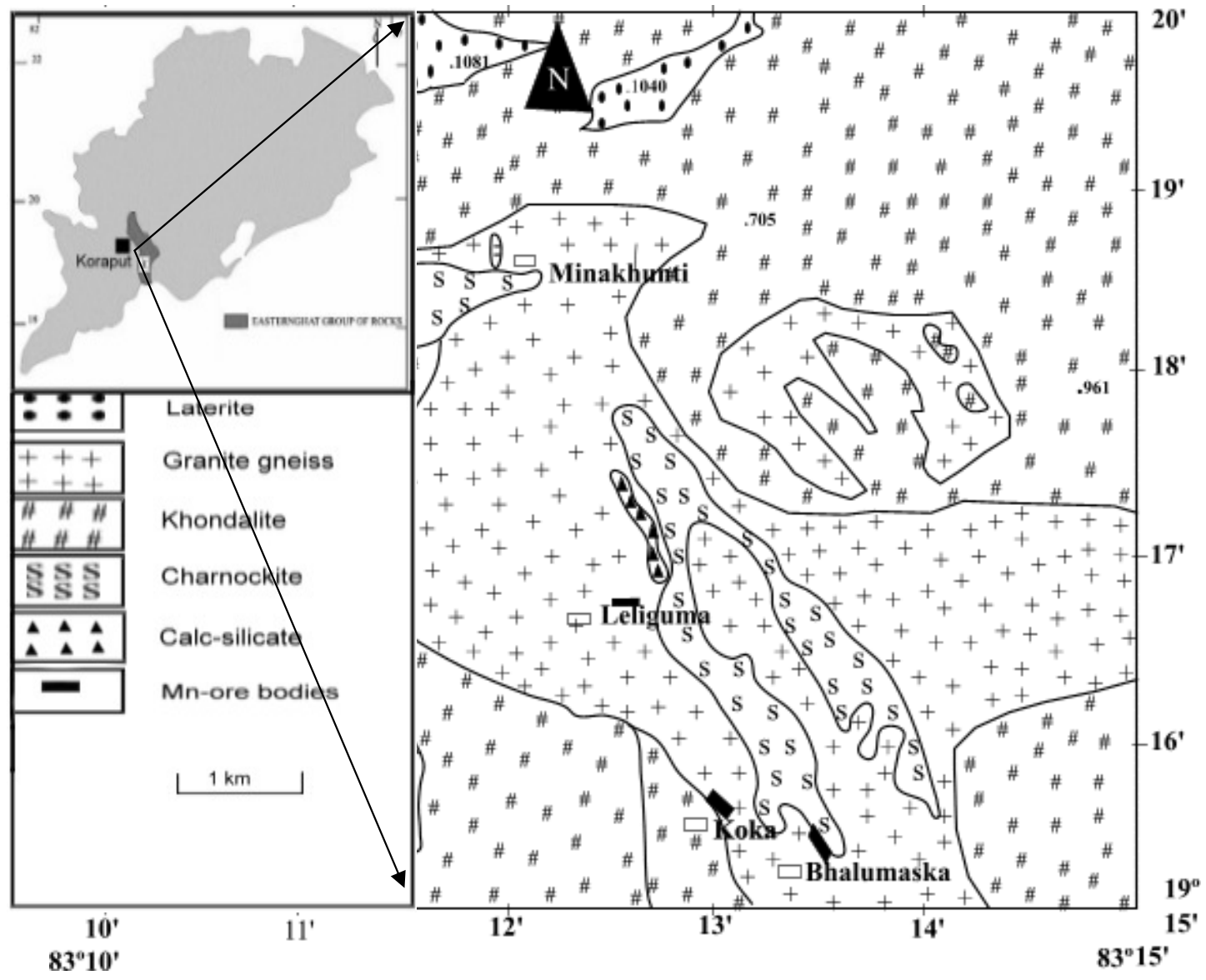

Fig. 1: Location and geological map showing manganese ore bodies in Leliguma-Koka sector, Koraput District, Orissa (survey of India Toposheet no. 65 M/3).

\section{MATERIALS AND METHODS}

Ten Mn-ore samples from stratabound ore deposit located at Leliguma, Koraput district, south Orissa, India (Fig.1) were collected and prepared for study under optical (Leitz, orthoplan) and electron microscope (JEOL). The identification of apatite and its microstructural peculiarities were obtained through these studies.

It was followed by compositional analysis through Electron Probe Micro analyzer (Jeol, JXA8100). The $\mathrm{Ca}, \mathrm{P}$ and other elemental analyses were carried out by wavelength dispersive methods using appropriate apatite standard.

The rare earth element analyses of apatite grains were performed with the aid of EPMA using accelerating voltage of $25 \mathrm{kv}$, a beam current of $20 \mathrm{nA}$, beam diameter of $2.5 \mu \mathrm{m}$ and $20 \mathrm{~s}$ counts. Synthetic glass and international standards FeR2 (G.S., Canada) and G2 (USGS) were used as standards for EPMA analysis. 


\section{RESULTS AND DISCUSSION}

The characteristics of apatite grains in Mn-ores, occurring in two different associations viz. silicate minerals (Ap1) and Mn-minerals (Ap2), were studied under optical and electron microscopes. Results are discussed below:

\subsection{Microstructure of Apatite}

The manganese ore in the stratabound ore body of study area constitutes two major mineral phases such as: manganese minerals and silicate minerals. Apatite is present in both these minerals and display different habits (Table 1).

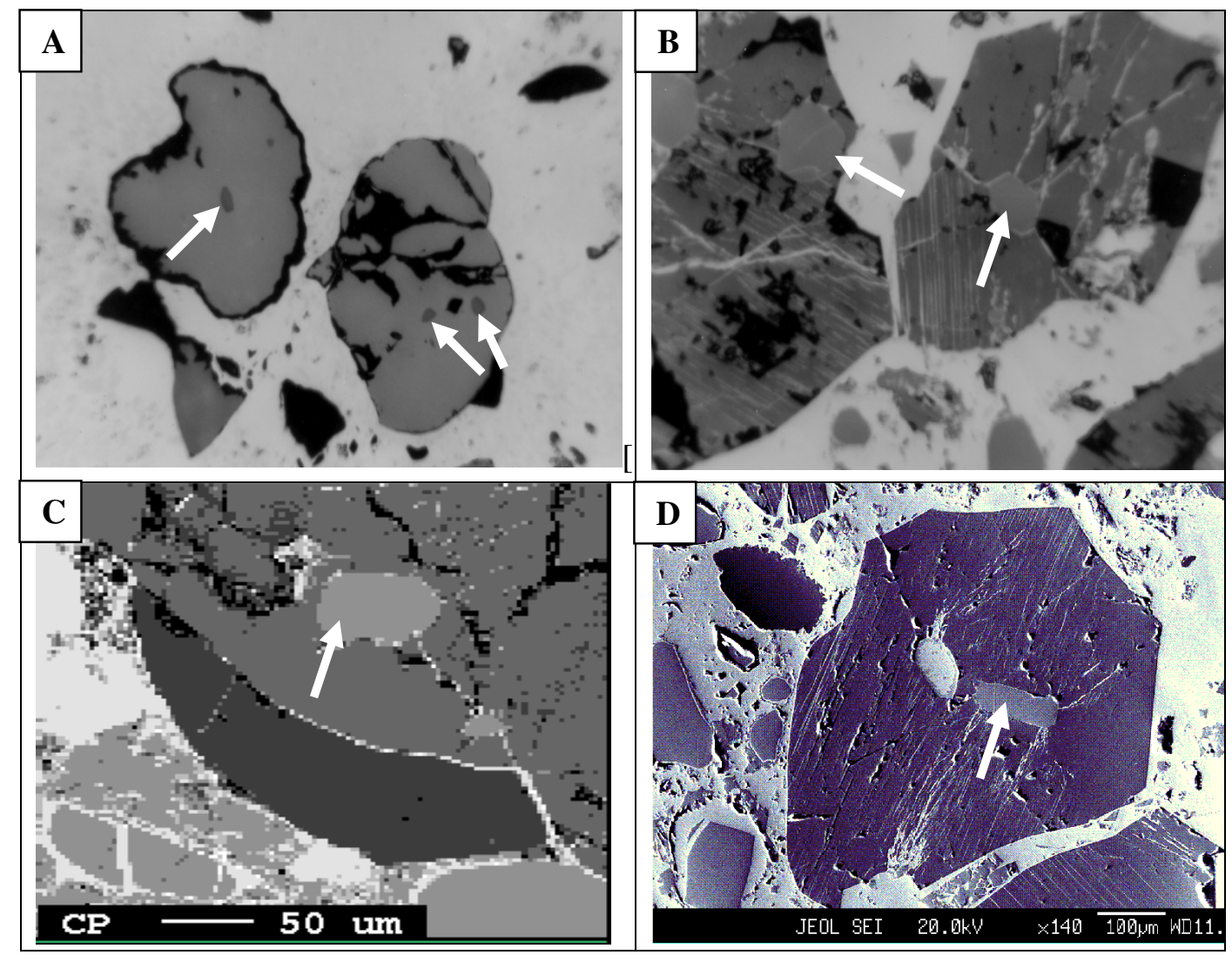

Fig. 2: Optical (A\&B) and electron micrographs (C\&D) of apatite in pegmatitic ( $)$ association

(A) Tiny grains of apatite within quartz $\mathrm{x} 100$

(B) Rounded to subrounded apatite grain within plagioclase feldspar x 200

(C) An ovoidal grain of apatite in orthoclase

(D) Elongated apatite grain in plagioclase 
Table 1: Characteristics of apatite in different association

\begin{tabular}{|l|l|l|}
\hline Characteristics & Pegmatitic association & Mn -mineral association \\
\hline Habit & Ovoidal, tear drop, elongated & $\begin{array}{l}\text { Columnar, lenticular, tiny irregular, } \\
\text { hexagonal, prismatic. }\end{array}$ \\
\hline Inclusion & $\begin{array}{l}\text { Apatite occur within quartz } \\
\text { and feldspar }\end{array}$ & $\begin{array}{l}\text { Apatite contains quartz and } \\
\text { feldspar, cryptomelane as inclusions. }\end{array}$ \\
\hline Other Characteristics & $\begin{array}{l}\text { Irregular contact with } \\
\text { enclosing minerals }\end{array}$ & Zoning, twinning and overgrowth. \\
\cline { 2 - 3 } & Mostly as isolated grains & Both as isolated grains and clusters \\
\hline
\end{tabular}
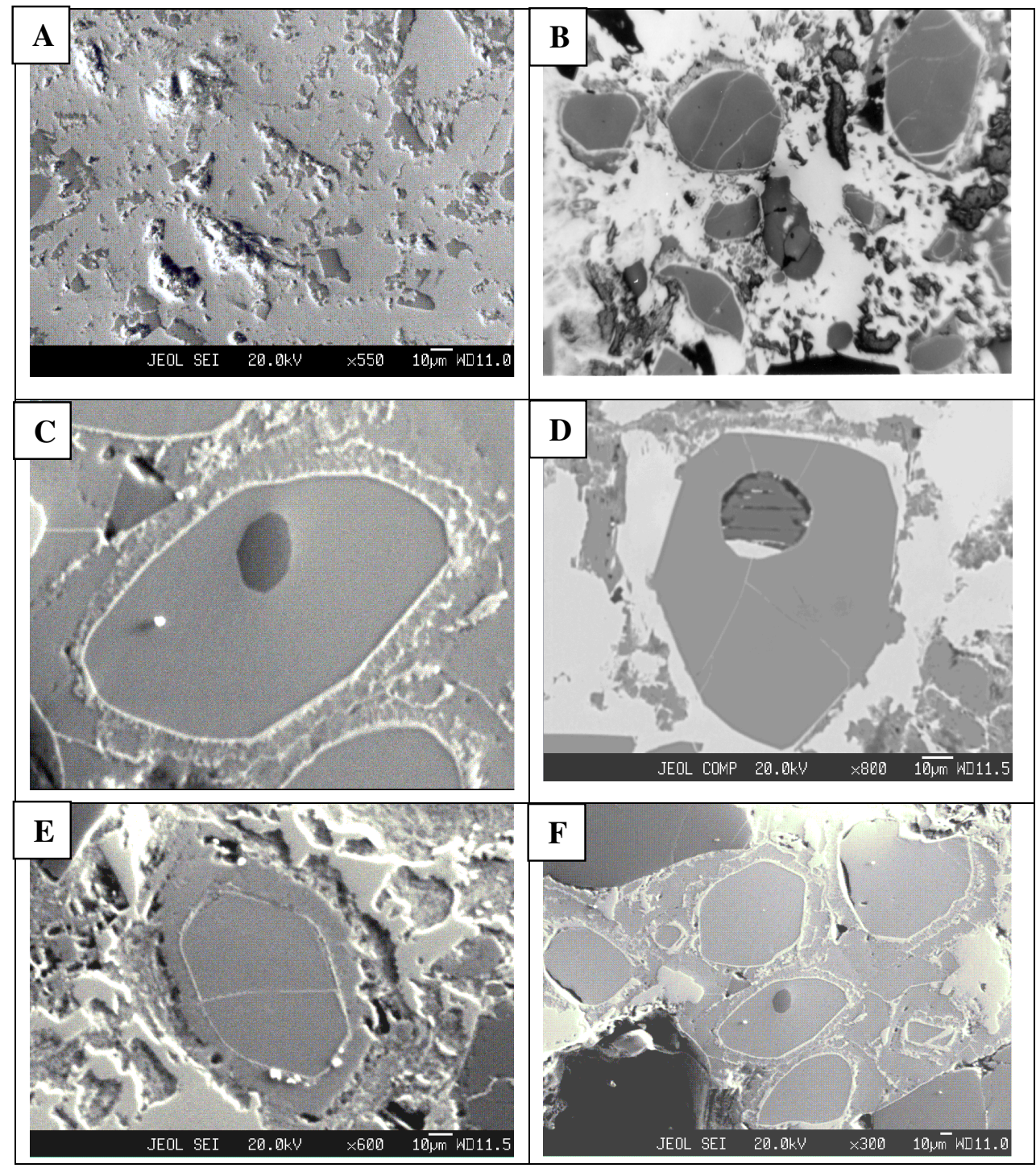

Fig. 3: Optical (B) and electron micrographs (A to E) in manganese association. (A)Tiny grains of apatite within cryptomelane. (B)Cluster of apatite grains in different size within cryptomelane x100. (C) Inclusion of quartz within apatite. (D)Inclusion of feldspar within apatite. (E) Apatite showing compositional zoning. (F)A large apatite grain containing small apatites of earlier generation. 


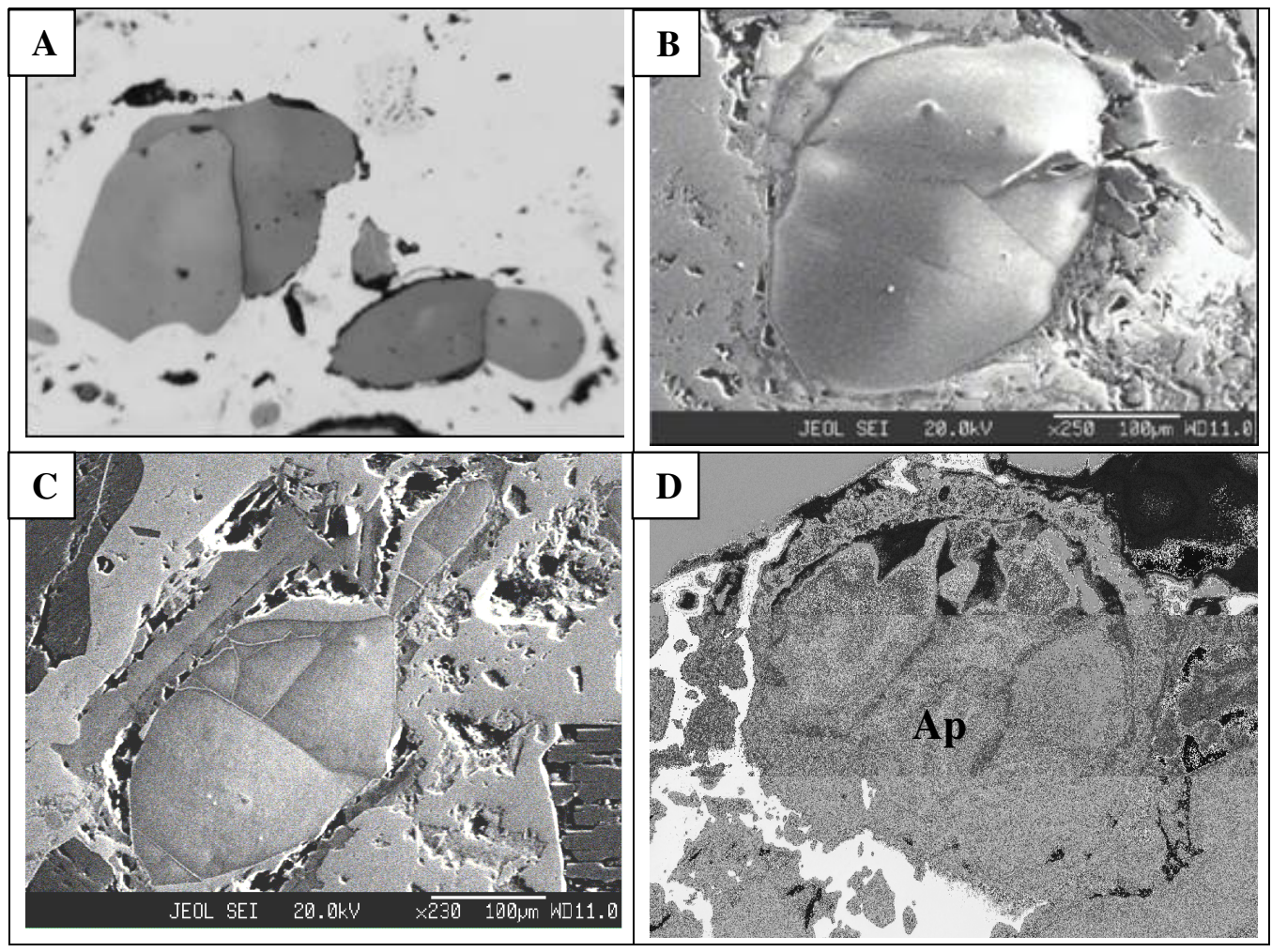

Fig. 4 : Optical (A\&D) and electron micrographs $(B \& C)$ of apatite in manganese association showing different morphology
(A) Twined apatite grains in cryptomelane base (white) x200
(B) An ovoidal grain of apatite showing overgrowth
(C) Apatite showing lenticular structure
(D) A subrounded broken apatite grain (Ap) with lithiophorite encrustation (L) x200

In general, apatite looks colourless to pale pink under petrographic microscope, shows grey interference colour and straight extinction. Apatite (Ap1), enclosed within quartz (Fig.2A), orthoclase (Fig.2B) and plagioclase (Figs. 2C \& D), is relatively less in modal percentage (2-3\%) compare to the one associated with manganese minerals (10\%). The apatite in silicate association is generally smaller in size ( $<100$ micron) and shows ovoidal, rounded to sub rounded or elongated shape with corroded outlines (Fig.2).

Apatite (Ap2) associated with manganese mineral occurs as very tiny grains (Fig.3A), as moderate size grains (20-50micron), in clusters or as euhedral crystals ( $>150$ micron, Fig.3B). Such apatite occasionally contains inclusions of quartz (Fig.3C) and feldspar (Fig.3D). Zoning in some apatite is distinctly seen (Fig.3E). Some layers in zoned apatite are often found to be replaced by cryptomelane. Occasionally, large apatite is observed to enclose small apatite grains of earlier generation (Fig.3F). Twinned apatite crystals (Fig.4A), apatite showing overgrowth (Fig.4B) and lenticular micro-structure (Fig.4C) are some of the features observed only in this type of association. Thin encrustation of lithiophorite (Fig. 4D) is rarely seen over sub rounded grain of apatite in the zone of lateritisation. 


\subsection{Compositional Characteristics of Apatite}

The analytical data of Ap1 and Ap2 (Tables 2 \& 3) reveal the following notable mineralchemical pattern. Apatite enclosed within quartz and feldspar minerals (Ap1) is almost devoid of manganese and shows higher concentration of $\mathrm{Sr}$ and LREE. The broad composition of apatite from this association is found out to be $\left[\mathrm{Ca}_{10.39-10.55} \mathrm{Mn}_{0-0.3} \mathrm{Sr}_{0.08-0.11}\right]\left(\mathrm{PO}_{4}\right)_{5.33-5.46} \mathrm{~F}_{1.71-2.32}$.

Total LREE content in these apatite grains is higher than the other variety (Ap2, Table 3). La and Pr are appreciably present in this apatite while Ap2 is almost free from them. Apatite associated with manganese mineral (Ap2) contains between 1.89 and $6.85 \% \mathrm{MnO}$ corresponding to the formula [Ca9.49-10.35 $\mathrm{Mn}_{0.27-1.05} \mathrm{Sr}_{0.0-0.03}$ ] $\left(\mathrm{PO}_{4}\right)_{5.26-5.54} \mathrm{~F}_{1.70-2.13}$ and may be termed as manganoan apatite or Mn-apatite. Total HREE content in Mn- apatite grains is higher than the Ap1 variety, (Table 3).

Table 2: EPMA results of apatite from two associations 1-5: Silicate Association; 6-10: Mn-association showing major compositional variation

\begin{tabular}{|l|c|c|c|c|c|c|c|c|c|c|c|c|}
\hline $\mathrm{Wt} \%$ & 1 & 2 & 3 & 4 & 5 & Avg. & 6 & 7 & 8 & 9 & 10 & Avg. \\
\hline $\mathrm{CaO}$ & 54.20 & 55.01 & 54.79 & 54.76 & 55.22 & 54.80 & 54.1 & 54.62 & 54.1 & 50.82 & 48.66 & 52.46 \\
\hline $\mathrm{MnO}$ & 0.22 & 0.23 & 0.06 & 0.07 & 0.20 & 0.16 & 3.15 & 2.18 & 1.89 & 4.43 & 6.85 & 3.70 \\
\hline $\mathrm{P}_{2} \mathrm{O}_{5}$ & 36.01 & 36 & 35.10 & 34.95 & 35.55 & 35.52 & 35.31 & 36.16 & 35.37 & 36.51 & 35.11 & 35.69 \\
\hline $\mathrm{F}$ & 2.98 & 4.11 & 2.99 & 3.95 & 4.22 & 3.65 & 3.52 & 3.01 & 3.81 & 2.99 & 3.15 & 3.30 \\
\hline $\mathrm{Sr}$ & 0.72 & 0.66 & 0.68 & 0.78 & 0.96 & 0.76 & 0.03 & 0.05 & 0.04 & 0.22 & 0.17 & 0.10 \\
\hline $\begin{array}{l}\mathrm{H}_{2} \mathrm{O} \\
\text { (by diff.) }\end{array}$ & 5.87 & 3.99 & 6.38 & 5.49 & 3.85 & 5.12 & 3.89 & 3.98 & 4.79 & 5.03 & 6.06 & 4.75 \\
\hline
\end{tabular}

..On the basis of 16 cations......................................

\begin{tabular}{|l|c|c|c|c|c|c|c|c|c|c|}
\hline $\mathrm{Ca}$ & 10.39 & 10.45 & 10.54 & 10.55 & 10.49 & 10.20 & 10.27 & 10.35 & 9.74 & 9.49 \\
\hline $\mathrm{Mn}$ & 0.03 & 0.03 & 0 & 0 & 0.02 & 0.40 & 0.32 & 0.27 & 0.67 & 1.05 \\
\hline $\mathrm{Sr}$ & 0.08 & 0.08 & 0.08 & 0.09 & 0.11 & 0.03 & 0 & 0 & 0.02 & 0.02 \\
\hline $\mathrm{Total}$ & 10.50 & 10.56 & 10.62 & 10.64 & 10.62 & 10.63 & 10.59 & 10.62 & 10.43 & 10.56 \\
\hline $\mathrm{P}$ & 5.46 & 5.41 & 5.35 & 5.33 & 5.34 & 5.26 & 5.38 & 5.35 & 5.54 & 5.42 \\
\hline $\mathrm{F}$ & 1.71 & 2.27 & 1.73 & 2.22 & 2.32 & 2.02 & 1.70 & 2.13 & 1.72 & 1.80 \\
\hline $\begin{array}{l}\text { Apatite \& } \\
\text { member }\end{array}$ & 99.44 & 99.44 & 100 & 100 & 99.72 & 96.24 & 6.98 & 97.46 & 93.58 & 90.06 \\
\hline $\begin{array}{l}\text { Manganese } \\
\text { \& member }\end{array}$ & 0.28 & 0.28 & - & - & 0.18 & 3.76 & 3.02 & 2.54 & 6.42 & 9.94 \\
\hline
\end{tabular}




\section{GENESIS OF APATITE}

The stratabound ore bodies are generally of epigenetic origin and formed during supergene processes due to remobilization and precipitation of Mn-rich fluid along structurally weak planes. The manganese rich fluid in Liliguma stratabound ore body has in all probability generated due to weathering of adjacent stratabound manganese ore and associated granitic and charnokitic rocks.

The mode of occurrence, microstructure and mineral chemistry of apatite in Mn-ores of Leliguma stratabound deposit reveal two different mode of origin. The apatite (Ap1) that occur as inclusion within quartz and feldspar, and contain less than $1 \% \mathrm{MnO}$, is inferred to be of hydrothermal origin, and developed during formation of pegmatitic minerals. Its irregular shape, poor Mn-value and enriched Sr (Table-2) \& LREE content (Table-3) support such interpretation. Apatite crystallizing from a granitic melt tends to concentrate the LREEs or the middle rare-earth elements relative to HREEs [5]. Further, actual REE distribution in particular depends not only on apatite structure, but also upon the REE distribution and chemical characteristics of melt or fluid reservoir from which the apatite crystallized.

Table 3: EPMA analysis results (wt \%) of apatite obtained from two different associations (1-5: Hydrothermal; 6-10: Supergene) showing LREE \& HREE distribution.

\begin{tabular}{|l|l|l|l|l|l|l|l|l|l|l|l|l|}
\hline $\begin{array}{l}\text { Compound, } \\
\text { in ppm }\end{array}$ & $\mathbf{1}$ & $\mathbf{2}$ & $\mathbf{3}$ & $\mathbf{4}$ & $\mathbf{5}$ & $\mathbf{A v g}$ & $\mathbf{6}$ & $\mathbf{7}$ & $\mathbf{8}$ & $\mathbf{9}$ & $\mathbf{1 0}$ & Avg. \\
\hline $\mathrm{La}_{2} \mathrm{O}_{3}$ & 0.12 & 0.17 & 0.02 & 0.29 & - & 0.12 & - & - & - & - & - & - \\
\hline $\mathrm{Ce}_{2} \mathrm{O}_{3}$ & 0.09 & - & - & 0.08 & 0.17 & 0.07 & 0.1 & 0.17 & - & 0.01 & 0.03 & 0.06 \\
\hline $\mathrm{Pr}_{2} \mathrm{O}_{3}$ & 0.09 & 0.01 & 0.06 & 0.03 & 0.06 & 0.08 & 0.11 & - & - & - & 0.13 & 0.05 \\
\hline $\mathrm{Nd}_{2} \mathrm{O}_{3}$ & - & 0.19 & 0.03 & 0.01 & 0.09 & 0.06 & - & 0.03 & 0.11 & 0.11 & 0.04 & 0.06 \\
\hline $\mathrm{Sm}_{2} \mathrm{O}_{3}$ & - & 0.04 & 0.02 & 0.03 & 0.07 & 0.04 & - & 0.06 & 0.08 & 0.01 & - & 0.03 \\
\hline $\mathrm{\Sigma LREE}$ & 0.3 & 0.41 & 0.13 & 0.44 & 0.39 & 0.37 & 0.21 & 0.26 & 0.19 & 0.13 & 0.2 & 0.2 \\
\hline $\mathrm{Eu}_{2} \mathrm{O}_{3}$ & 0.001 & - & 0.01 & 0.006 & 0.019 & 0.007 & 0.007 & 0.01 & 0.02 & 0.03 & 0.01 & 0.01 \\
\hline $\mathrm{Gd}_{2} \mathrm{O}_{3}$ & 0.06 & - & - & 0.11 & 0.17 & 0.07 & - & - & 0.09 & - & - & 0.02 \\
\hline $\mathrm{Tb}_{2} \mathrm{O}_{3}$ & 0.01 & 0.03 & - & 0.02 & 0.01 & 0.01 & - & 0.02 & - & 0.07 & 0.1 & 0.03 \\
\hline $\mathrm{Dy}_{2} \mathrm{O}_{3}$ & 0.02 & - & 0.21 & 0.18 & 0.02 & 0.09 & 0.29 & 0.43 & - & - & 0.53 & 0.25 \\
\hline $\mathrm{Ho}_{2} \mathrm{O}_{3}$ & 0.004 & 0.013 & 0.001 & 0.011 & - & 0.005 & 0.015 & 0.019 & - & 0.009 & - & 0.009 \\
\hline $\mathrm{Er}_{2} \mathrm{O}_{3}$ & - & 0.04 & 0.01 & 0.07 & 0.03 & 0.04 & 0.002 & 0.04 & 0.05 & 0.08 & 0.08 & 0.05 \\
\hline $\mathrm{Tm}_{2} \mathrm{O}_{3}$ & 0.005 & 0.004 & 0.006 & - & 0.006 & 0.004 & 0.004 & 0.006 & 0.009 & 0.006 & 0.009 & 0.006 \\
\hline $\mathrm{Yb}_{2} \mathrm{O}_{3}$ & 0.02 & 0.01 & 0.01 & - & 0.03 & 0.01 & 0.04 & 0.14 & 0.44 & - & 0.03 & 0.03 \\
\hline $\mathrm{Lu}_{2} \mathrm{O}_{3}$ & 0.014 & 0.006 & 0.001 & 0.011 & - & 0.006 & 0.001 & 0.01 & 0.02 & 0.01 & 0.03 & 0.01 \\
\hline $\mathrm{\Sigma HREE}_{2}$ & 0.134 & 0.103 & 0.248 & 0.428 & 0.285 & 0.245 & 0.359 & 0.56 & 0.22 & 0.20 & 0.78 & 0.42 \\
\hline
\end{tabular}

(-) not detected 
Manganoan apatites (Ap2) in other association (with cryptomelane / romanechite) are formed after Mn-Ca-P rich fluid emplacement along structurally weak planes of granitic rock. The secondary growth of apatite is indicated by the presence of quartz and feldspar inclusions, its composition (having $6.85 \%$ of $\mathrm{MnO}$ in solid solution Table-2), relatively low LREE and high HREE content (Table-3).

Knutson et al [10] reported that zoning is developed due to repeatedly renewed growth or rhythmic changes in the chemical composition between different zones, which points to variation from time to time in the chemical concentration of elements in depositing solution. The compositional variation between different layers in zoned apatite, brought out through line scanning under EPMA (Fig. 5), is in agreement with Knutson [10] in the growth of this apatite in the study area. Presence of Mn-layers in zoned apatite attests to their secondary development. Quartz and feldspar inclusions within apatite probably indicate that apatite was grown over these clasts from solution. Skeletal overgrowth is also marked by compositional discontinuity between core and rims. Such features reveal to rhythmic growth of apatite. Small apatite grains enclosed within larger grain (Fig.3F) also supports growth at different interval. Idiomorphic crystal habit and lenticular structure are probably developed (Fig. 3C) during latter period.

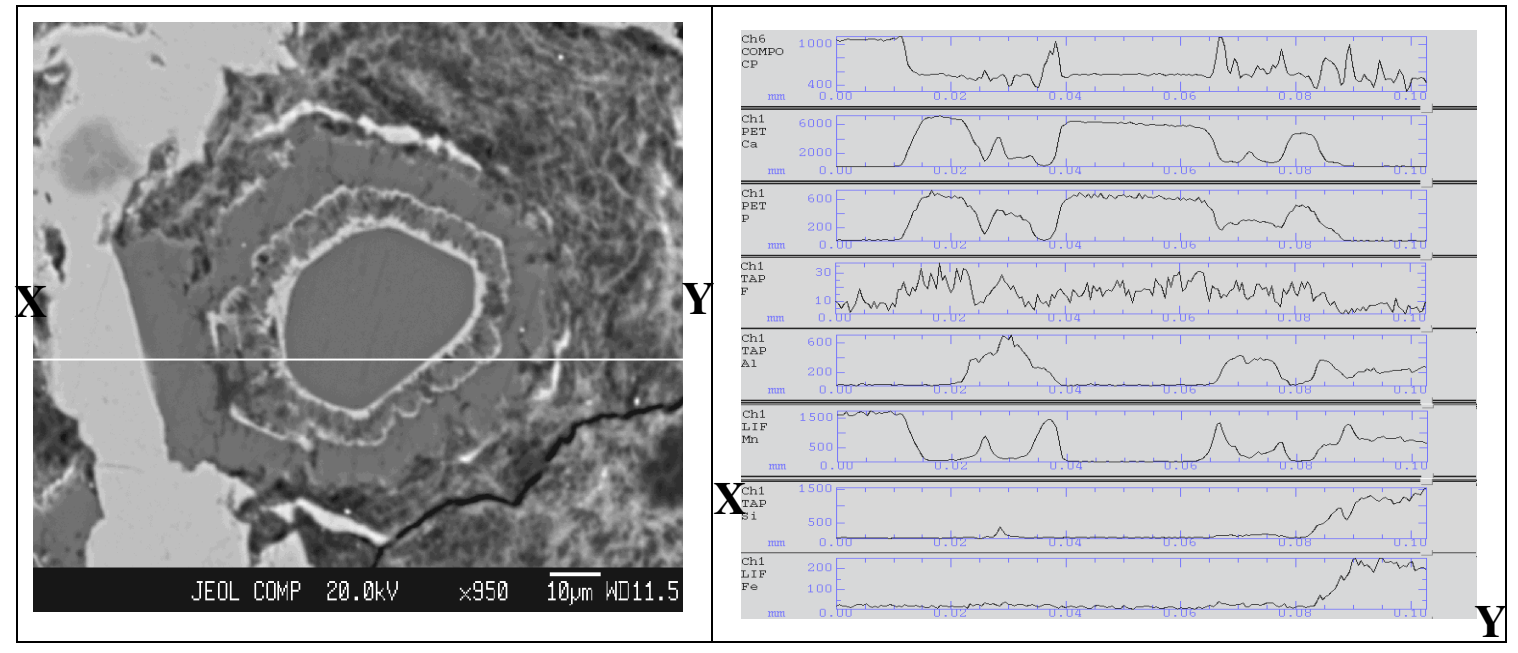

Fig. 5: Line scan profile showing the compositional variation along a line (X-Y) shown across the zoned apatite

Dual source of apatite is thus evidenced from their association, micromorphology, microstructure and chemical composition. Subhedral apatite (Ap1) is of hydrothermal origin and formed along with quartz and feldspar in the granite/pegmatite (country rock). The euhedral Manganoan apatites (Ap2) are formed during supergene process and developed in a latter period.

Higher HREE in latter apatite is related to their availability in the mineral rich fluid from which apatite formed. The REE chemistry of bulk Leliguma manganese ore shows relatively higher HREE value than adjacent stratiform Mn-ores located at Koka. The higher HREE value in the bulk Mn-ore may thus be attributed to apatite (Ap2) 


\section{CONCLUSIONS}

From the foregoing discussions the following conclusions are made:

1. Apatite in stratabound Mn-ores of Eastern Ghats Group of rocks at Koraput dist., Orissa, India shows bimodal distribution, viz i) enclosed within silicate minerals (Ap1) and ii) the other associated with manganese minerals (Ap2).

2. Ap1 grains are subhedral, poor in $\mathrm{MnO}$ but have relatively enriched $\mathrm{Sr}$ and LREE contents. In contrast, Ap2 are euhedral crystals and show typical features like twinning, zoning, overgrowth and lenticular structure. Ap2 is rich in manganese content (MnO: 0.89 to $6.85 \%$ ) and may be termed as manganoan apatite. HRE elements in these apatite crystals are relatively higher compared to other type (Ap1).

3. Apatite (Ap1) enclosed within quartz and feldspar are formed along with other granitic/ pegmatitic minerals. Higher LREE and $\mathrm{Sr}$ contents indicate the source solution to be hydrothermal in nature. Euhedral apatite (Ap2) associated with manganese mineral phase is developed at a latter stage, during supergene process. These are sometime grown over clasts of different composition (quartz, feldspar and apatite grains).

4. Contrasting microstructure and composition of apatite in stratabound manganese ore bodies indicate their dual source: one being hydrothermal formed along with granitic/pegmatitic minerals (country rock) and other of secondary, supergene origin formed along with stratabound ore body.

\section{ACKNOWLEDGEMENTS}

The authors are thankful to Prof. B.K. Mishra, Director, Institute of Minerals and Materials Technology, Bhubaneswar, Orissa, India for his kind permission to publish this paper.

\section{REFERENCES}

[1] HENDERSON, P. (1980) Rare earth element partition between sphene, apatite and other minerals of the Kanger intrusion, Greenland. Contributions to Mineralogy and Petrology, $72,81-85$.

[2] KORALENKO, V.I., ANTIPEN, V.S., VLADYKIN. N.V., SNEIRNOVA, YE.V., and BALASHOV. Magmatic processes, Geochemistry International, v. 19, pp. 171.

[3] ROEDER, P.L., MACARRTHUR, D., MA, XIN-PEI, PALMER, G.L. and MARIANO, A.N. (1987) Cathode luminescence and micro-probe study of rare earth elements in apatite. Am. mineral v.72, pp.801-811.

[4] RONSBO, J.G. (1989). Coupled substitution involving REEs and $\mathrm{Na}$ and $\mathrm{Si}$ in apatites in alkaline rocks from the Illimaussaq intrusion, South Greenland, and the petrological implications. Amer. Min., v.74, pp. 896-901.

[5] PAPIKE, J.J., JENSEN, M., SHEARER, C.K., SIMON, S.B., WALKER, R,J., and LAUL, J.C. (1984) Apatite as a recorder of pegmatite petrogenesis, Geological Society of American Abstracts with Programs,v.16, pp.617. 
[6] SHMAKIN, B.M. and SHIRYAYEVA, V.A. (1968) Distribution of rare earths and some other elements in apatites of muscovite pegmatites, Eastern Siberia. Geokhimiya, v.8, 962969 (transl. Geochemistry International, pp.796-803.

[7] ROY, S, (1972). Some observations on Grade, Quality and Problems of Beneficiation of Manganese Deposits of Different Genetic Types (Abstract). Proc.Ind.Sci. Cong., 59 ${ }^{\text {th }}$ Session, Section V, pp.274-275.

[8] BHATTACHARYA, S., KRISHNA RAO, S.V.G. and SARMA, K. J. (1984) On the nature of phosphorus in the manganese ores of Grabham-Garividi belt of Eastern Ghats, India. Ind. Min., v.38 (2), pp. 39-42.

[9] ACHARYA, B.C., RAO, D.S., SAHOO, R.K. and DASH, B. (1994) Phosphorus in the siliceous manganese ores of Nisikhal, Orissa. Ind. Jour. of Geol., v.66, no.1. pp. 15-23.

[10] KNUTSON,C., Peacor, D.R., and KELLY, W.C. (1985) Luminiscence, color and fission track zoning in apatite crytstals of the Parasequence tin-tugsten deposits, Beira-Baixa, Portugal, American Mineralogist,v.70, pp. 829-837. 